Original Research Article

\title{
Evaluation of antioxidant and hepatoprotective property of ethanolic extract of curculigoorchioides in albino rats
}

\author{
Jacob Jesurun R. S. ${ }^{1}$, Johan Pandian J. ${ }^{2 *}$
}

\begin{abstract}
${ }^{1}$ Department of Pharmacology, Believers Church Medical College and Hospital, Thiruvalla, Kerala, India ${ }^{2}$ Department of Pharmacology, Mahatma Gandhi Medical College and Research Institute, Pillayarkuppam, Pondicherry, India
\end{abstract}

Received: 23 January 2019

Revised: 17 May 2019

Accepted: 30 May 2019

\section{*Correspondence to: \\ Dr. Johan Pandian J, \\ Email: johanpandian@ gmail.com}

Copyright: (C) the author(s), publisher and licensee Medip Academy. This is an openaccess article distributed under the terms of the Creative Commons Attribution NonCommercial License, which permits unrestricted noncommercial use, distribution, and reproduction in any medium, provided the original work is properly cited.

\begin{abstract}
Background: Liver, the largest organ invertebrate body, it the major site of intense metabolic activities. Being the largest chemical factory of the body, the liver performs innumerable functions. The functional units of liver are called either hepatic or classic lobules or acini. The hepatic lobules consist largely of parenchymal or epithelial glandular cells called hepatocytes, which are arranged as interconnected plates or laminae.
\end{abstract}

Methods: All the animal experiments were conducted according to the ethical norms approved by Ministry of Social Justices and Empowerment, Government of India, and Institutional Animal Ethical Committee guidelines. Fifteen rats were selected for this study and randomly divided into three groups of five each. Group I include control rats that received isocarolic quantity of sucrose in the same volume as experimental rats that received ethanol. Group II includes ethanol treated rats. Ethanol was administered daily at regular intervals by gastric intubation at a dose of as $20 \%$ aqueous solution $1 \mathrm{ml}$ for 60 days. Group III includes ethanol $(1 \mathrm{ml}$ of $25 \%)+$ Curculigoorchioides rhizome $(80 \mathrm{mg} / \mathrm{kg} \mathrm{b} . \mathrm{wt})$ treated rats for 60 days, daily at regular intervals by gastric intubation.

Results: The effect of ethanol alone and ethanol+curculigoorchioides rhizome extract (combined) on adult male rat liver metabolism were assessed in the present study and compared with the control rate. The mean body weight of ethanol treated rats was lesser than control and ethanol+curculigoorchioides rhizome extract treated rats. (Table 1, Figure 1) Data on liver weight from control, ethanol alone and ethanol+curculigoorchioides extract (combined) treated rats did not show much variation (Table 1, Figure 2).

Conclusions: The effect of curculigo orchioides rizhomes extract+ethanol (combined) on adult male rat liver metabolism was assessed in the present study and compared with control and ethanol alone treated rats. The administration of ethanol accelerates the glycogenolysis and drastically reduced the hepatic glycogen content. The hepatic transaminase activity was swayed by ethanol treatment and reverted to normalcy by combined treatment. Elevated levels of serum enzyme are indicative of cellular leakage and loss of functional integrity of cell membrane in liver. The reversal of altered transaminase activities to normal by plant extract supplementation suggest its hepatoprotective action.

Keywords: Curculigo orchioides, Hepatic transaminase, Liver

\section{INTRODUCTION}

Liver, the largest organ invertebrate body, it the major site of intense metabolic activities. Being the largest chemical factory of the body, the liver performs innumerable functions. The functional units of liver are called either hepatic or classic lobules or acini. The hepatic lobules consist largely of parenchymal or epithelial glandular cells called hepatocytes, which are arranged as interconnected plates or laminae. In addition to the hepatic cells, there are 
two other types of cells, the typical endothelial cells and large Kupffer cells. The Kupffer cells are a type of macrophages, capable of phagocytizing bacteria and other foreign matter. Kupffer cells line the hepatic sinusoids and constitute an important part of the reticulo endothelial system of the body. ${ }^{1,2}$

In rats and mice, hepatocytes constitute $90 \%$ of all masses and $60 \%$ nuclear population. Bile duct cells constitute the remaining $5 \%$ of the nuclear population of liver cells. The biliary passages begin as tiny bile canaliculi formed by adjacent parenchymal cells. The main hepatic duct joins the cystic duct from the gall bladder to form the common bile duct, which drains into the duodenum. ${ }^{3,4}$

The liver synthesizes and secretes bile, plasma, proteins such as albumin, globulin, macroglobulins, hepatoglobulins, thyroid hormone binding globulin, fibrinogen, ceruloplasmin, transferrin and anticoagulant heparin (Sherlock 1981). Liver also stores iron, copper, fat soluble vitamins A, D, E, K and detoxify drugs or poison by activating oxidizing, hydrolyzing, reducing and demethylating enzymes.,

\section{METHODS}

\section{Chemicals}

All the chemical and reagents were obtained from Sigma chemical company USA and Sarabhai M chemicals India. Dried rhizomes of curculigoorchioides were collected from local market of Chennai city, Tamil Nadu and authenticated in Plant Science Department of K.M.C.P.G.S, Puducherry. Curculigoorchioides rhizome powder was prepared from the dry rhizomes. The powder was dissolved in distilled water and used.

\section{Bovin's fluid}

Bovin's fluid was prepared by mixing the following chemicals. Picric acid (saturated)-75 ml, Formaldehyde (940\%)-25 ml, Glacial acetic acid-5 ml.

\section{Preparation of eosin and haematoxylin}

Eosin-1 g, Alcohol 95\%-25 ml, Distilled water-75 ml

\section{Animals}

Healthy adult male albino rats of wistar strain (rattusnorvegicus) weighing 150-240 g if body weight and 90 days old were used. The rats were kept in clean polypropylene cages in a temperature-controlled room with 12 hours light/dark schedule. They were fed with balanced diet with free access of water.

All the animal experiments were conducted according to the ethical norms approved by Ministry of Social Justices and Empowerment, Government of India, and Institutional Animal Ethical Committee guidelines. Fifteen rats were selected for this study and randomly divided into three groups of five each.

\section{Group I}

Group I include control rats that received isocarolic quantity of sucrose in the same volume as experimental rats that received ethanol.

\section{Group II}

Group II includes ethanol treated rats. Ethanol was administered daily at regular intervals by gastric intubation at a dose of as $20 \%$ aqueous solution $(1 \mathrm{ml}$ ) for 60 days.

\section{Group III}

Group III includes ethanol (1ml of 25\%) + curculigoorchioides rhizome $(80 \mathrm{mg} / \mathrm{kg}$ b.wt) treated rats for 60 days, daily at regular intervals by gastric intubation.

On the next day of last i.e: 60th day oral administration animal after recording the weight in each, they were sacrificed by decapitation. Blood was collected from jugular vein by making an incision. Collected blood was allowed to clot for 20-30 min. Serum was separated by centrifugation at $37^{\circ} \mathrm{C}$ and used for estimation of various biochemical parameters. Liver of each animal was excised and placed in chilled saline $\left(4^{\circ} \mathrm{C}\right)$ to remove excess of blood and adhering fibrous tissues. The weight of livers was noted. the livers were homogenized in the respective solution/buffer and centrifuged at $3000 \mathrm{rpm}$ for $10 \mathrm{~min}$. The supernatant was used for the biochemical estimations.

\section{Histological studies}

The classic paraffin sectioning and haematoxylin-eosin staining techniques were used for histological studies.

\section{Ehrlich's haematoxylin}

Haematoxylin-1g, Absolute alcohol-10ml, Potassium alum-20g, Mercuric oxide-0.5g, Distilled Water-200ml, Glacial acetic acid- $8 \mathrm{ml}$. The solution was mixed thoroughly and exposed to light for six weeks to ripen the solution.

\section{Fixation}

Liver was fixed in bovin's fluid as soon as they were excised. The tissues were fixed in the bovin's fluid for 48 hours. After 48 hours, the tissue was taken out and washed in running tap water for a day to remove excess picric acid.

\section{Dehydration}

For dehydration, isopropyl alcohol was used. The tissue was passed through the following series of alcohol: $30 \%$, $50 \%, 70 \%, 90 \%$ (one hour in each) and $100 \%$ (half an 
hour, twice). Care was taken to have optimum dehydration.

\section{Clearing}

Xylol was used as the clearing agent for 1 to 2 hours with two to three changes.

\section{Infiltration or Impregnation}

The tissue was taken out of xylene and kept in a molten paraffin was bath in metal pots. The temperature of the molten wax was maintained at about $58^{\circ} \mathrm{C}$. The tissue was given 3 changes in the molten wax at 30 minutes intervals.

\section{Embedding}

The paraffin wax was heated up to the optimum melting point $\left(56^{\circ} \mathrm{C}-58^{\circ} \mathrm{C}\right)$ and maintained at the temperature till embedding. A clean glass plate was smeared with glycerine and ' $L$ ' shaped models were placed on it to form rectangular cavity. The molten paraffin was poured slowly, and the air bubbles were removed by using a hot needle. The tissue was placed in the paraffin and oriented with the surface to be sectioned. Then, the tissue was pressed gently towards the glass plates to make the tissues settle uniformly with metal pressing rod and allowed the wax to settle and solidify at room temperature. The paraffin block was kept in cold water for cooling.

\section{Section cutting}

Section cutting was done with rotary microtome (ERMA), Germany. To produce uniform section, the microtome knife was adjusted to the proper angle in the knife holder with only the cutting edge coming in contact with the paraffin block and section of $5 \mu$ thickness were cut.

\section{Flattening and mounting of section}

The sections were spread on a warm water bath, after they were detached from the knife with the help of hairbrush. Dust-free clean slides were coated with egg albumin over the whole surface. Required number of sections were spread on the clean slide and kept at the room temperature.

\section{Staining}

The sections were stained as follows

Deparaffinization treatment with xylol two times, each for 5 minutes. Hydration through descending grades of isopropylalcohol (2minutes) $90 \%$ alcohol, $70 \%$ alcohol and 50\% (1 minute in each) Staining with Ehreich's for 1520 minutes. Thorough washing in tap water and blowing for 10 minutes. Rinsing with distilled water thoroughly. Staining with Eosin. Dehydration again with ascending grades of alcohol $70 \%$ alcohol (2minutes), 90\% alcohol and $100 \%$ (absolute) alcohol (2 minutes). Clearing up xylol for two times, each at 3 minutes of interval.

\section{Mounting}

On the stained slide, the DPX mountant was applied uniformly and micro glass cover slide was placed gently, avoiding air bubbles. The slides were observed under microscope (NIKON) and microphotography was performed.

\section{Biochemical analysis}

\section{Estimation of protein}

The protein content was determined by the method of Lowry et al.

\section{Procedure}

$0.1 \mathrm{ml}$ of extracts were taken and made up to a final volume of $1 \mathrm{ml}$ with distilled water. $5 \mathrm{ml}$ of alkaline copper reagent was added, mixed and allowed to stand at room temperature for 10 minutes. Then, $0.5 \mathrm{ml}$ of Folin ciocalteau was added to this and shaken well. The blue colour developed was read against reagent blank at $720 \mathrm{~nm}$, after 20 minutes, in a spectrophotometer. The amount of protein present in the sample was calculated by referring to the standard curve obtained. The total protein content is expressed as $\mathrm{mg} / 100 \mathrm{mg}$ of wet tissue.

\section{Estimation of glucose}

The glucose concentration was measured by the enzymatic method of Trinder.

\section{Procedure}

$1 \mathrm{ml}$ of glucose oxidase and $50 \mu 1$ of sample were mixed in a test tube. $2 \mathrm{ml}$ of phenol solution added to all test tubes and shaken well. The mixture was placed at $37^{\circ} \mathrm{C}$ water bath for 15 minutes. The absorbance was measured at $515 \mathrm{~nm}$ against the reagent blank. The standard also runs along the sample to calculate the concentration of glucose in the sample.

\section{Estimation of glycogen}

Glycogen was estimated by the method of Hassid and Abraham.

\section{Procedure}

A known amount of tissue was digested with $1 \mathrm{ml}$ of $30 \%$ potassium hydroxide for 20 minutes in a boiling water bath. The digest was cooled in an ice bath and $1.25 \mathrm{ml}$ of 95\% ethanol was added. The contents were thoroughly mixed and gently brought to boil in a hot water bath. This was cooled and centrifuged for 15 minutes at $3000 \mathrm{Xg}$. the supernatant was decanted, and the tubes were allowed to drain on a filter paper for a few minutes. The precipitate was dissolved in $1 \mathrm{ml}$ of distilled water, precipitated with $1 \mathrm{ml}$ of $95 \%$ ethanol, centrifuged and drained as before. 
The precipitate was dissolved in $5 \mathrm{ml}$ of distilled water and $10 \mathrm{ml}$ of $0.2 \%$ anthrone reagent was added under ice cold conditions. The tubes were covered with glass marbles and heated for 10 minutes in a boiling water bath. the contents were cooled immediately, and the colour was read at $620 \mathrm{~nm} .5 \mathrm{ml}$ of water and $5 \mathrm{ml}$ of standard solution containing $0.1 \mathrm{mg}$ glucose were treated with anthrone reagent and subjected to the same procedure and they served as blank and standard, respectively. The amount of glycogen was calculated from the following equation.

\section{$(100 \times \mathrm{X}) /(1.11 \times \mathrm{S})$}

Where, U-optical density of unknown,

S-Optical density of $0.1 \mathrm{mg}$ glucose standard

1.11-morris factor for the conversion of glucose to glycogen with this equation.

Glycogen concentration is expressed as $\mathrm{mg}$ per $100 \mathrm{mg}$ tissue.

\section{Estimation of acid phosphatase: (EC 3.1.3.2)}

\section{Procedure}

To the clean test tubes labeled test and blank, $0.5 \mathrm{ml}$ of substrate was pipetted. To this $0.5 \mathrm{ml}$ of citrate buffer was added. The tubes were placed in a water bath at $37^{\circ} \mathrm{C}$ for 5 minutes. The reaction was initiated by the addition of $0.1 \mathrm{ml}$ of the sample to the test tube and $0.1 \mathrm{ml}$ of distilled water to the blank. Exactly, after 30 minutes of incubation at $37^{\circ} \mathrm{C}$, the reaction was arrested by the addition of $3.8 \mathrm{ml}$ of $0.1 \mathrm{~N}$ sodium hydroxide. The reaction product, paranitrophenol was measured at $415 \mathrm{~nm}$ against the blank in the spectrophotometer. Suitable standards were run along with the assay. The enzyme activity is calculated by referring to the calibration curve, obtained using free paranitrophenol. Acid phosphatase activity is expressed as $\mu$ moles of paranitrophenol formed per hour per $\mu \mathrm{g}$ of protein.

\section{Estimation of alkaline phosphatase (E.C. 3.1.3.1):}

Alkaline phosphatase was assayed following the method of Bessey et al.

\section{Procedure}

To the tubes labeled test and blank, $0.5 \mathrm{ml}$ of para nitro phenyl phosphate and $0.5 \mathrm{ml}$ of glycine buffer were added. The tubes were placed in a water bath at $37^{\circ} \mathrm{C}$ for 5 minutes. The reaction was initiated by the addition of $0.1 \mathrm{ml}$ of sample to the test and $0.1 \mathrm{ml}$ of distilled water to the blank. Exactly, after 30 minutes of incubation at $37^{\circ} \mathrm{C}$ the reaction was arrested by the addition of $10 \mathrm{ml}$ of sodium hydroxide. The tubes were mixed well and the colour developed was read at $410 \mathrm{~nm}$, in a spectrophotometer, against the blank. $0.1 \mathrm{ml}$ of concentrated hydrochloric acid added, mixed and the optical density was read at 400nm against the blank. The difference in the two absorbances was taken as the measure of enzyme activity, suitable standards were run along with the assay.

The alkaline phosphatase activity was calculated from the calibration curve obtained, using para nitro phenol standard. Alkaline phosphatase activity is expressed as $\mu$ moles of para nitro phenol formed per hour per $\mu \mathrm{g}$ protein.

\section{Statistical analysis}

The data obtained were subjected to statistical analysis and expressed as Mean \pm SEM (standard error mean). The SEM was calculated by the following formula.

$$
\text { S.E.M }
$$

$$
=\sqrt{\sum_{x} 2-\left[\sum x\right]} 2
$$

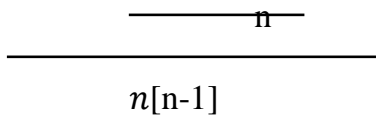

$\mathrm{X}=$ individual observation

$\mathrm{N}=$ number of observations

Student's ' $t$ ' test was used to calculate the degree of significance by the formula given below

$$
\begin{aligned}
& \mathrm{t}=\frac{\bar{x}_{1-\bar{x}_{2}}}{S} \mathrm{X} \sqrt{\frac{n 1 \times n 2}{n 1+n 2}} \\
& \mathrm{~S}=\sqrt{\sum\left(x 1-\bar{x}_{1}\right)} 2+\sum\left(x 2-\bar{x}_{2}\right) 2 \\
& \mathrm{n}_{1}+\mathrm{n}_{2}-2
\end{aligned}
$$

$\mathrm{N} 1$ and $\mathrm{N} 2$ are the number of observations in the two classes being compared. From the degree of freedom, values of probability were obtained from the standard table given by Fisher and Yates. If the calculated value is more than the table value, it is significant at the probability level.

\section{RESULTS}

The effect of ethanol alone and ethanol+curculigoorchioides rhizome extract (combined) on adult male rat liver metabolism were assessed in the present study and compared with the control rate.

The mean body weight of ethanol treated rats was lesser than control and ethanol+curculigoorchioides rhizome extract treated rats. (Table 1, Figure 1).

Data on liver weight from control, ethanol alone and ethanol+curculigoorchioides extract (combined) treated rats did not show much variation (Table 1, Figure 2). 
Table 1: Effect of ethanol and curculigo orchioides rhizomes on total bod weight and liver weight of male adult rats.

\begin{tabular}{|lll|}
\hline Group & $\begin{array}{l}\text { Body } \\
\text { weight } \\
\text { (gm) }\end{array}$ & $\begin{array}{l}\text { Liver weight } \\
\text { (gm/100 gm } \\
\text { body weight) }\end{array}$ \\
\hline Control & $198 \pm 14.62$ & $3.798 \pm 0.480$ \\
\hline Ethanol & $182 \pm 8.08$ & $4.236 \pm 0.347$ \\
\hline Ethanol+Plant Extract & $192 \pm 6.75$ & $3.408 \pm 0.272$ \\
\hline
\end{tabular}

Each value is Mean \pm SEM of five animals.

Table 2, Figure 3-5 depicts the data on liver protein, glucose, and glycogen in control, ethanol alone and ethanol+curculigoorchioides extract combined treated male rats. The total soluble protein content was found to be reduced in both ethanol alone and ethanol+ curculigoorchioides extract combined group than control group rats. However, the reduction was more pronounced in ethanol alone treated $(\mathrm{P}<0.05)$ group compared to control rat liver. The concentration of protein in ethanol+ curculigoorchioides extract combined group was marginally more than ethanol group, but lesser than control animals. However, the values are statistically insignificant.

The quantity of glycogen in liver tissue was recorded more in control rats than other two groups. In combined treated animal rat, the concentration of glycogen was marginally higher than ethanol alone treated groups. The quantity of glycogen was significantly $(\mathrm{P}<0.05)$ lower in ethanol alone treated animals than control animals, though the concentration glycogen in ethanol+curculigoorchioides extract (combined) was found to be more than ethanol alone group and lesser than control group, but the values are statistically insignificant. The hepatic glucose content remains unswayed by any of these experimental treatments.

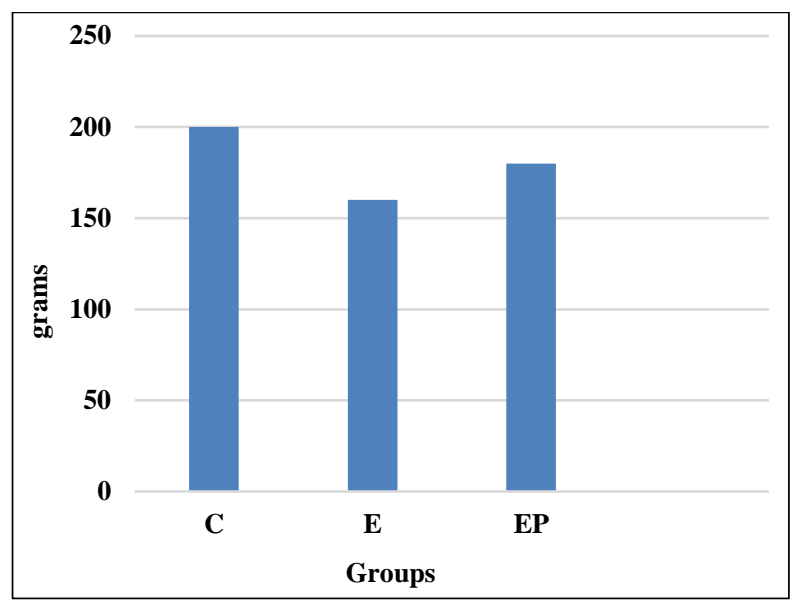

Figure 1: Effect of ethanol and curculigo orchioides rhizomes on total body weight of male adult rats.

Table 2: Effect of ethanol and curculigo orchioides rhizomes on male adult rat liver protein, glucose and glycogen (mg/100mg wet tissue).

\begin{tabular}{|llll|}
\hline Group & Protein & Glucose & Glycogen \\
\hline Control & $12.26 \pm 0.950$ & $4.722 \pm 0.501$ & $14.426 \pm 0.846$ \\
\hline Ethanol & $* 5.7918 \pm 0.523$ & $4.55 \pm 0.16$. & $* 7.32 \pm 0.752$ \\
\hline Ethanol+ Plant Extract & $9.456 \pm 0.920$ & $4.208 \pm 0.310$ & $12.874 \pm 0.803$ \\
\hline
\end{tabular}

Each value is Mean \pm SEM of five animals

$*=\mathrm{P}<0.05$ Control $(\mathrm{C})$ Vs Ethanol treated animals $(\mathrm{E})$

Table 3: Effect of ethanol and curculigo orchioides rhizomes on adult male rat liver phosphomonoesterases ( $\mu$ moles of paranitrophenol formed $/ \mathrm{hr} / \mu \mathrm{g}$ protein) and transaminases (units / mg protein).

\begin{tabular}{|lllll|}
\hline Group & Acid phosphatase & Alkaline phosphatase & Aspartate transaminase & Alanine transaminase \\
\hline Control & $0.562 \pm 0.029$ & $8.724 \pm 0.80$ & $42.444 \pm 3.263$ & $27.356 \pm 2.188$ \\
\hline Ethanol & $0.598 \pm 0.056$ & $* 3.204 \pm 0.382$ & $* * * 18.58 \pm 2.686$ & $* * 15.222 \pm 1.157$ \\
\hline $\begin{array}{l}\text { Ethanol+ } \\
\text { Plant extract }\end{array}$ & $0.556 \pm 0.029$ & $\mathrm{a} 8.252 \pm 0.512$ & $\mathrm{~b} 36.542 \pm 2.097$ & $\mathrm{a} 23.776 \pm 1.138$ \\
\hline
\end{tabular}

Each value is Mean \pm SEM of five animals.

$*=\mathrm{P}<0.05 ; * *=\mathrm{P}<0.01 ; * * *=\mathrm{P}<0.001$ Conrtol $(\mathrm{C})$ Vs Ethanol $(\mathrm{E})$ treated animals

$\mathrm{a}=\mathrm{P}<0.05 ; \mathrm{b}=\mathrm{P}<0.01 ;$ Ethanol $(\mathrm{E})$ treated Vs Ethanol + Plant Exteact (EP) treated.

The activities of phosphomonoestuases and transaminases were also measured in liver tissue of control, ethanol alone and ethanol+curculigo orchioides extract (combined) treated male rats.
The results obtained from this experiment is presented in Table 3 and Figure 6 and 7. The ethanol alone and combined with curculigo orchioides extract did not alter significantly the acid phosphatas from these two groups 
showed a narrow variation than the control rat liver. The alkaline phosphatase activity was decreased in ethanol alone and ethanol and curculigo orchioides extract (combined) treated rat liver.

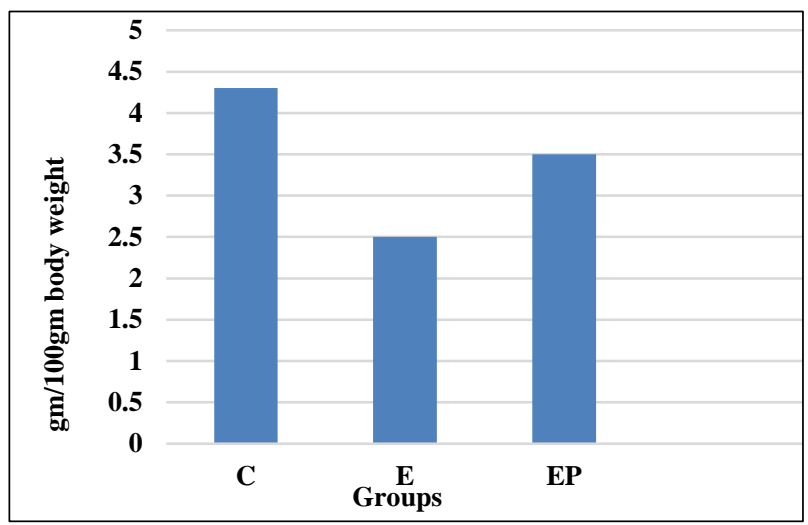

Figure 2: Effect of ethanol and curculigo orchioides rhizomes on liver weight of male adult rats.

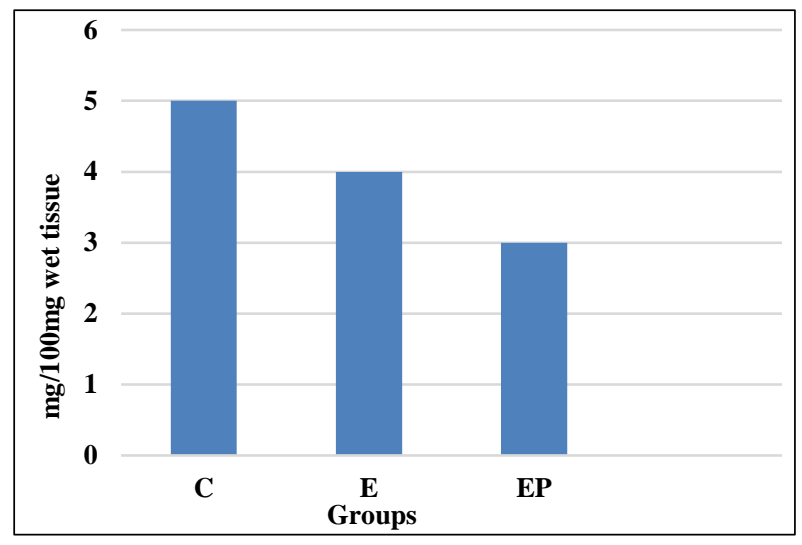

Figure 3: Effect of ethanol and curculigo orchioides rhizomes on male adult rat liver protein.

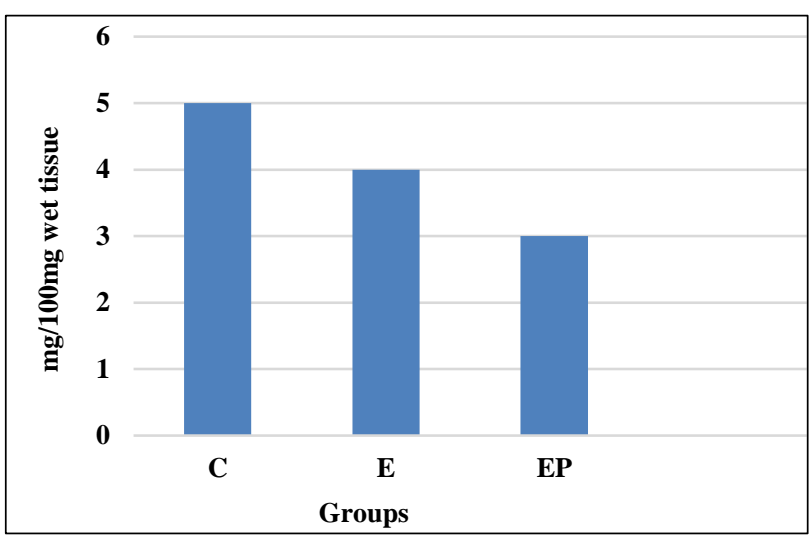

Figure 4: Effect of ethanol and curoculigo orichioides rhizomes on male adult rat liver glucose.

The difference was more $(\mathrm{P}<0.05)$ between control group and ethanol alone treated group rats. Variation of alkaline phosphatase activity was also noticed between ethanol alone and ethanol+curculigo orchioides combined-treated animals. $(\mathrm{P}<0.05)$.

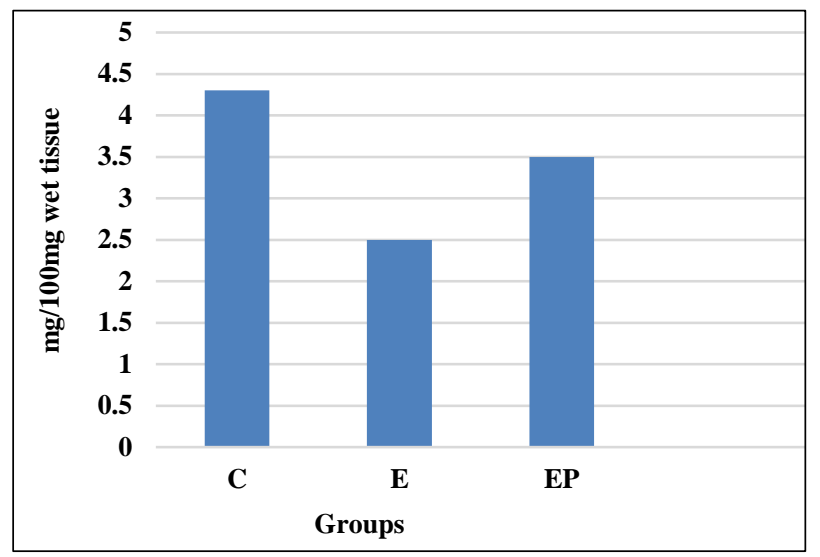

Figure 5: Effect of ethanol and curculigo orchioides rhizomes on male adult rat liver glycogen.

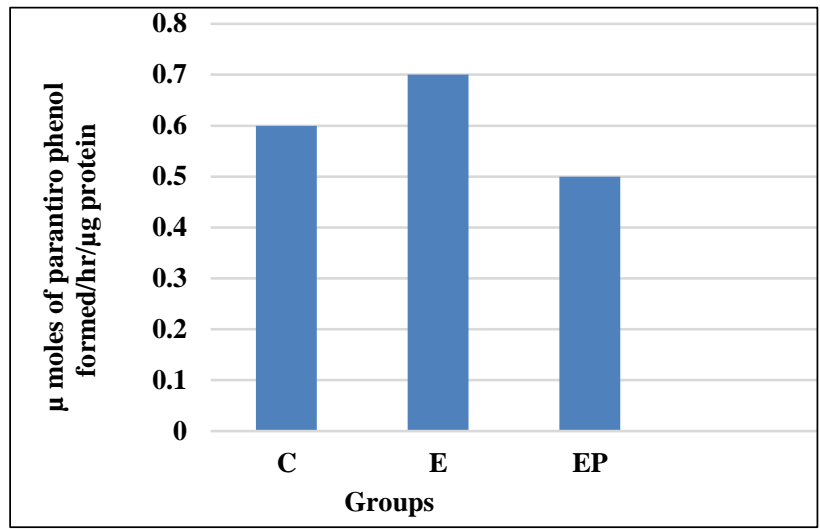

Figure 6: Effect of ethanol and curculigo orchioides rhizomes on male adult rat liver acid phosphatase.

Interestingly, the levels of transaminases in liver exhibit a wide variation in these three studied group rats. (Figure $8,9)$ In general the activities of liver aspartate transaminase and alanine transaminase were suppressed by ethanol treatment to adult male rats. Comparatively, the control rat liver recorded maximal value of aspartate transaminase and alanine transaminase than the remaining group rats.

The aspartate transaminase activity was found to be lesser in ethanol group liver than control rats $(\mathrm{P}<0.001)$ and ethanol+curculigo orchioides extract (combined) $(\mathrm{P}<0.01)$ -treated rats. The variation between control and ethanol+curculigo orchioides combined treated rat liver Alanine transaminase activity was minimal.

Similarly, the activity of liver alanine transaminase was also swayed by ethanol alone treatment and brought back to near control values by combined treatment. It was recorded that the activity of liver alanine transaminase in ethanol alone treated rat deviates from that of control and ethanol+curculigo orchioides combined treatment. The value of liver alanine transaminase was lesser in ethanol 
group than control $(\mathrm{P}<0.01)$ and ethanol+curculigo orchioides combined-treated $(\mathrm{P}<0.05)$ rats.

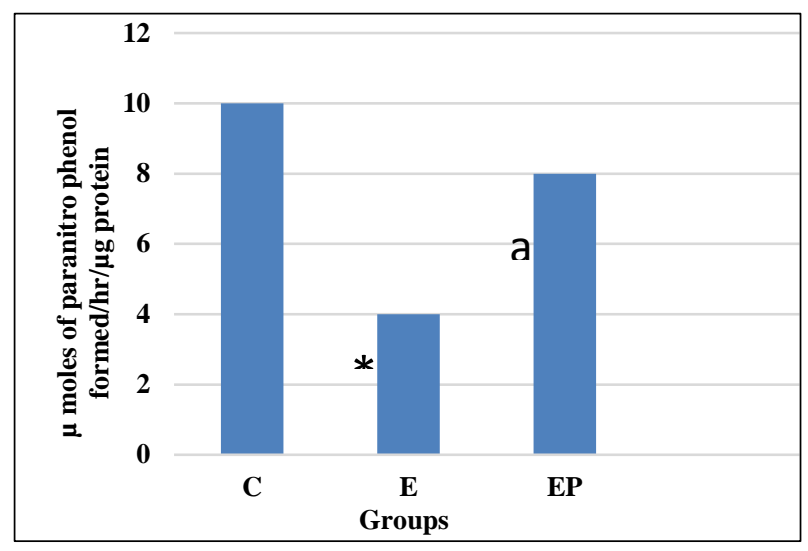

Figure 7: Effect of ethanol and curculigo orchioides rhizomes on adult male rat liver alkaline phosphatas.

In addition to above mentioned liver tissue biochemical parameters, some selected serum biochemical profiles were also studied in ethanol alone and ethanol+curculigo orchioides extract combined treated rats and matched with control rat serum values. The quantity of glucose, bilirubin, transaminases, phosphomonoesterases (Table 4) and lipid profile were measured in serum samples of three different group of rats, which are directly / indirectly related to liver functions.

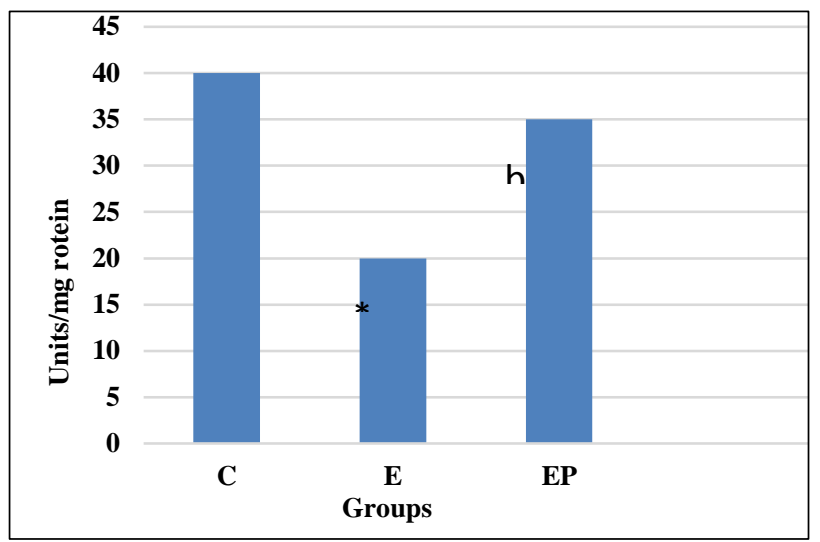

Figure 8: Effect of ethanol and curculigo orchioides rhizomes on adult male rat liver asparate transaminase.

Table 4: Effect of ethanol and curculigo orchioides rhizomes on serum glucose (mg/dl), bilirubin (mg/dl), transaminase $(\mu / \mathrm{l})$ andphosphomonesterase $(\mu / 1)$ in adult male rats.

\begin{tabular}{|lllllll|} 
Group & Glucose & $\begin{array}{l}\text { Aspartate } \\
\text { Transaminase }\end{array}$ & $\begin{array}{l}\text { Alanine } \\
\text { Transaminase }\end{array}$ & Bilirubin & ACP & ALP \\
\hline Control & $22.92 \pm 2.880$ & $284 \pm 20.661$ & $94.6 \pm 8.98$ & $0.7 \pm 0.07$ & $30.956 \pm 1.752$ & $424.2 \pm 31.240$ \\
\hline Ethanol & $21.38 \pm 2.645$ & $* * * 410.6 \pm 34.24$ & $* * * 196.2 \pm 12.71$ & $* 1.52 \pm 0.241$ & $28.532 \pm 1.407$ & $* * * 1283 \pm 35.286$ \\
\hline $\begin{array}{l}\text { Ethanol+ } \\
\text { Plant extract }\end{array}$ & $21.52 \pm 2.662$ & $\mathrm{c} 263 \pm 17.99$ & $\mathrm{c} 77.8 \pm 7.294$ & $0.82 \pm 0.08$ & $28.154 \pm 2.535$ & $* \mathrm{c} 598.6 \pm 35.286$ \\
\hline
\end{tabular}

Each value is Mean \pm SEM of five animals,

$*=\mathrm{P}<0.05 ; * * *=\mathrm{P}<0.001$ Control $(\mathrm{C})$ Vs Ethanol $(\mathrm{E})$ treated animals

$*=\mathrm{P}<0.001$; Ethanol $(\mathrm{E})$ treated Vs Ethanol + Plant Extract (EP) animals.

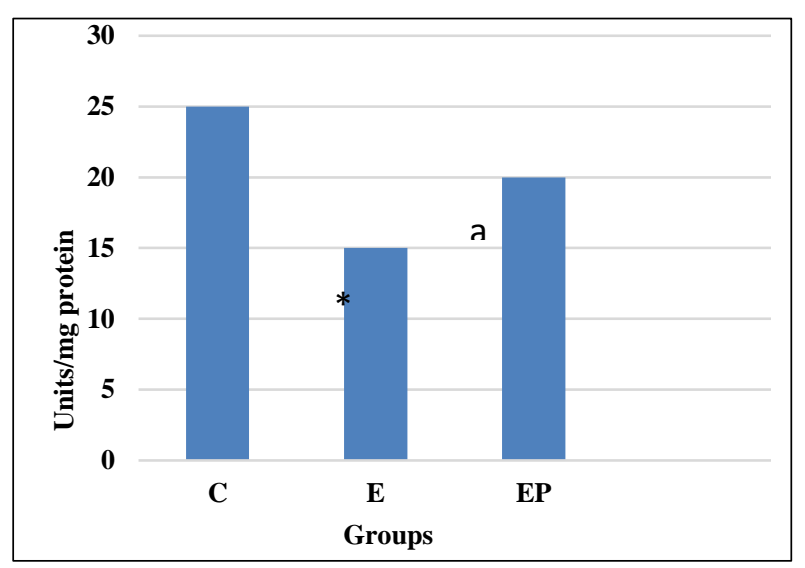

Figure 9: Effect of ethanol and curculigo orchioides rhizomes on adult male rat liver alanine transaminase

The ethanol alone and ethanol+Curculigo orchioides extract combined treatment did not alter the circulatory level of glucose in rats. (Figure 4), elevated level of total bilirubin was recorded in serum samples of ethanol alone treated rats whereas the co administration of ethanol and curculigo orchioides extract reversed the total bilirubin level to that of control serum level. The quantity of total bilirubin was higher in ethanol alone.

\section{DISCUSSION}

In the present work, an attempt was made to study the influence of ethanol and curculigo orchioides rhizomes extract on liver biochemical parameter in male albino adult rats. Liver is the major metabolic centre and plays a vital role in intermediate metabolism of different macromolecules like carbohydrate, proteins and lipids. Consumption of alcohol reaches primarily the liver through intestinal absorption and then metabolized into acetaldehyde by alcohol dehydrogenase and results in formation of free radicals. Chronic alcoholism produces a 
wide spectrum of liver and other organ diseases, depending on the amount and duration of alcohol intake. ${ }^{7,8}$

The mean body weight of ethanol alone and curculigo orchioides rhizomes extract+ethanol combined treated rats were compared with control rats. Variation of body weight was noticed among the three group in the present study. Lesser mean body weight was seen in the rats belongs to ethanol-treated group than control and curculigo orchioides rhizomes+ethanol combined-treated groups. The reduced adipose tissue may be the fore most cause of lower body weight, that ethanol is known to reduce the fat mass. The observed weight gain in curculigo orchioides rhizomes extract+ethanol treated group than ethanol group suggest the differential response of growth rate to the plant extract. ${ }^{9}$ The wet weight of liver was also determined in control, ethanol alone and ethanol+curculigo orchioides rhizomes extract combined-treated group rats. The mean weight of liver in all these three groups did not show much variation. Administration of ethanol for 60 days to adult male rat caused a reduction of protein content in liver tissue than control rats. Earlier study also demonstrated the decreased of content of protein in liver treated with alcohol (Soliman et al, Kumar et al,). ${ }^{10}$

\section{CONCLUSION}

The effect of curculigo orchioides rizhomes extract+ ethanol (combined) on adult male rat liver metabolism was assessed in the present study and compared with control and ethanol alone treated rats.

The administration of ethanol accelerates the glycogenolysis and drastically reduced the hepatic glycogen content. The hepatic transaminase activity were swayed by ethanol treatment and reverted to normalcy by combined treatment. Elevated levels of serum enzyme are indicative of cellular leakage and loss of functional integrity of cell membrane in liver. The reversal of altered transaminase activities to normal by plant extract supplementation suggest its hepatoprotective action.

The increased activity of the hydrolytic enzyme acid phosphatase in ethanol group was attributed to the damage in lysosomal membrane. The restoration of acid phosphatase activity in plant extract+ethanol combined treated group indicates the antihepatotoxic effect of curculigo orchioides. The altered serum lipid profiles in response to chronic alcoholism was found to be recovered towards normal value inethanol+curculigo orchioides rhizome extract treated rats. The attainment of near normalcy in serum lipid profiles of herb treated rats, unearthing the hepatoprotective effect of curculigo orchioides rhizome. Stabilization of serum bilirubin levels, through the administration of plant extract is a further clear indication of the improvement of liver functions.
The simultaneous supplement of rhizome extract with ethanol to animals revealed a better improved status of hepatic biochemical parameters indicating the hepatoprotective effect of curculigo orchioides in ethanolinduced oxidative stress.

\section{Funding: No funding sources}

Conflict of interest: None declared

Ethical approval: The study was approved by Ministry of Social Justices and Empowerment, Government of India, and Institutional Animal Ethical Committee guidelines

\section{REFERENCES}

1. Adolorato G, Carpristo E, Grieco A, Stefanini GF, Gasbarrini G. Influence of chronic alcohol abuse on body weight and energy metabolism. Is excess consumption a risk factor for obesity or malnutrition?. Intero Med. 1998;244(5):387-95.

2. Andersch MA, Szeczypinski AJ. Use of p-nitrophenyl phosphate as the substrate for determination of serum acid phosphatase. Am J Clin. Pathol. 1947;17(7):5714.

3. Angelico F, Ben DM, Conti R, Francioso S, Feole K, Maccioni D, et al. Non-alcoholic fatty liver syndrome: a hepatic consequence of common metabolic diseases. J Gastroenterol Hepatol. 2003;18(5):588-94.

4. Arulkumaran KSG, Rajasekaran A, Ramasamy R, Jegadeesan M, Kavimani S, Somasundaram A. Cassia roxburghii seeds protect liver against toxic effects of ethanol and carbontetrachloride in rats. International J Pharm Tech Res. 2009;1(2):273-6.

5. Babich LG, Shlykov SG, Borisova LA. (2002) Effect of ethanol on intracellular ca++ metabolism. Ukr Biokhim Zh. 2002;74(1):19-26.

6. Bailey SM,Cunningham CC. Effect of dietary fat on chronic ethanol induced oxidative stress in hepatocytes. Alcoho Clil Expe Res. 1999;23(7):12108.

7. Bailey SM, Cunningham CC (2002) Contribution of mitochondria to oxidative stress associated with alcoholic liver disease. Free Radical Biology and Medicine. 2002;32(1):11-6.

8. Bellentani S, Saccocio G, Masutri F, Giacca M, Miglioli L, Monzoni A, et al. Risk factors fox alcoholic liver disease. Addict Biol. 2002;5(3):261-8.

9. Bessey. OA, Lowery OH, Brock MS, (1946) A method for the rapid determination of alkaline phosphatase with fire cubic millimeters of serum. $\mathbf{J}$ Biol Chem. 1946;164:321-30.

10. Kapur V, Pillai KK, Hussain SZ Balani DK. Hepatoprotective activity of Jigrine on liver damage caused by alcohol. Carbon tetrachloride and paracetamol in rats. Ind J Pharmacol.1994; 26(1):3540 .

Cite this article as: Jacob JRS, Pandian JJ.

Evaluation of antioxidant and hepatoprotective property of ethanolic extract of curculigoorchioides in albino rats. Int J Basic Clin Pharmacol 2019;8:168592. 